\title{
Tracheal Hemorrhage
}

National Cancer Institute

\section{Source}

National Cancer Institute. Tracheal Hemorrhage. NCI Thesaurus. Code C78642.

Bleeding originating from the trachea. 